\title{
Educating Your State Legislators ${ }^{1}$
}

\author{
Stacey Ellison ${ }^{2}$
}

Both legislators and citizens play important roles in ensuring a fair and effective state government. It is the responsibility of elected State Representatives and Senators to represent the will of their constituents. Similarly, it is the responsibility of citizens to educate their Representatives and Senators on how issues may impact them and other local citizens. Understanding how the legislative process works and keeping abreast of issues will help you express your own thoughts confidently. Visiting "Online Sunshine: The Official Internet Site of the Florida Legislature" (leg. fl.us) is a good first step. Note the legislative calendar. When does session begin? When will legislators be in Tallahassee? When will they be in committee? Timing your communication is important.

There are many methods for communicating with your legislators, and you may choose to communicate your stance on issues through more than one method. Legislators receive many phone calls, emails, and letters each day. To make sure your message stands out, whether you call, email, or visit in person, you will want to remember some basic good practices.

- Make sure your legislator knows you are a constituent and a voter.

- Be aware of the legislative timeline. Are the legislators in session? Are they still in committee? This can impact what they are able to accomplish during the legislative cycle.

- Know what you want and ask for a specific action (e.g., support or opposition to a bill).

- Be honest and courteous.

- Make sure to clarify that this issue has wide impacts across your community.

- Make sure to keep your communications clear of jargon with which the legislator may not be familiar. Remember, they don't know everything about every issue, and it's your duty as a citizen to educate them. Be sure to keep communication positive and proactive. It is good to be direct, but negativity can hurt anyone's ability to listen objectively, legislators included.

- Take every opportunity to share appropriate literature and information with your legislators.

- Timing is important. If your legislator needs to take action tomorrow, a phone call or email will be appropriate. However, if you have more time, a personal letter or visit may make a greater impact.

- Keep to the point and discuss only one issue.

- Legislators are busy, so be prepared to communicate with a legislative aide in place of the legislator. Treat everyone who works for the legislator with the same respect and

1. This document is 4H397, one of a series of the 4-H Youth Development Program, UF/IFAS Extension. Original publication date February 2019. Visit the EDIS website at https://edis.ifas.ufl.edu for the currently supported version of this publication.

2. Stacey Ellison, regional specialized 4-H Extension agent, 4-H Youth Development Program, Northeast District; UF/IFAS Extension, Gainesville FL, 32611.

The Institute of Food and Agricultural Sciences (IFAS) is an Equal Opportunity Institution authorized to provide research, educational information and other services only to individuals and institutions that function with non-discrimination with respect to race, creed, color, religion, age, disability, sex, sexual orientation, marital status, national origin, political opinions or affiliations. For more information on obtaining other UF/IFAS Extension publications, contact your county's UF/IFAS Extension office. 
professionalism you would use with a legislator. They can be great allies in your cause.

- Always say thank you.

\section{Written Communications (Postal Mail or Email)}

- Address your communication to:

The Honorable John Doe

State Senator (or Representative), District \#

The Capitol

Tallahassee, FL 32399-1100

- Write on personalized stationary or letterhead.

- If sending postal mail, be sure to include your return address on the envelope and the letter. Sometimes the two may be separated.

- Identify yourself as a voter and a constituent.

- State your issue in the first sentence or two. Be clear, concise, and specific with which actions you wish for your legislator to take.

- Support your opinion with facts.

- Don't send the same letter or email to more than one legislator. The more personalized you can be, the better. Form letters simply do not have as much impact as your personal stories and messages.

- If sending an email, use a meaningful subject line that includes information about the issue you wish to discuss.

- Ask your legislators to explain their position on the issue.

\section{Phone}

- Speak clearly and courteously.

- Plan to be brief. It helps to make notes on your points, so you can stick to the most important items first.

- Be prepared to leave a voicemail. Your voicemail might be, "This message is for Representative or Senator X. [State your name and phone number.] I am calling to let you know I [oppose/support] S/HB \#. [State the reasons you support or oppose the bill briefly.]" Finish by restating your name and phone number.

\section{In-Person Meeting}

- Meeting your legislators is one of the most memorable and therefore effective ways to communicate with them.

- If possible, make an appointment in advance, and arrive on time. Legislators' schedules are very busy. They often cannot confirm appointment times until a week or even a couple of days in advance.

- Address elected officials by the correct salutations-Representative or Senator.

- Keep groups to not more than four or five people visiting with the legislator at a time.

- Plan two presentations, one five minutes or less and an extended version that can run up to 15 minutes. You never know if the legislator will need you to be brief or if they will have extra time to discuss your issue.

- Business professional attire is preferable.

- Start by briefly introducing yourself and your organization (if appropriate), and quickly sum up what you need from the Legislator.

- Make sure to leave appropriate handouts about the issue (flyers, infographics, etc.)

- Besides sharing the facts, be ready to share personal stories to demonstrate how the issue impacts you and your community. Remember, legislators are people, and people tend to remember stories far better than they remember lists of facts and statistics. The facts and statistics are important, too: provide those in your handouts.

- Ask your legislator about their opinion on the issue, and be prepared to defend yours in a professional and courteous manner.

- The staff also have a very important role; be sure to thank them for their time.

- Send personal thank-you notes to all (legislators and staff) with whom you interact.

\section{Giving Testimony}

- Citizens have the opportunity to give testimony at public hearings held by the legislature.

- To sign up to give testimony, contact the appropriate committee administrative assistant.

- Fill out an appearance card available online (Senate: (https://www.flsenate.gov/UserContent/Committees/ CommitteeAppearanceForm.pdf or House of Representatives: https://www.myfloridahouse.gov/), or do so in person at the committee.

- Plan to speak no longer than 3-5 minutes.

- Write and rehearse your speech in advance.

- Be respectful. Begin by saying, "Chairman/Chairwoman and members of the committee..." 
- In your testimony:

a. Identify yourself and your organization (if applicable).

b. Identify the bill by name and number, and state whether you are for or against the bill.

c. Recommend an action, and explain your recommendation.

d. Thank the committee.

- If several people are speaking from the same organization, make sure each person highlights different points.

- Be prepared to answer questions.

\section{Gather Support}

As an individual, your thoughts matter, but combining efforts with others whose opinions are similar to yours may have a larger impact. Some ways to include others in your case are:

- Spread information throughout your community and through social media.

- Create a petition (ipetitions.com).

- Attend a town hall meeting. Contact your legislator's office for scheduled meeting dates.

- Many grassroots organizations in your community may already be working on your issue of concern. Reach out to them. Connecting as citizens can be powerful.

- Pitch your issue to local media. They often act on tips from concerned citizens.

- Find champions. There are legislators who will be strong advocates for your cause. They may be your Representative or Senator, or they may be from a different geographic area. Either way, they know the ins and outs of the legislature and can be a great resource.

\section{Acknowledge Your Role as a}

\section{Citizen}

Congratulate yourself for being an active citizen. It is through the work of citizens like you that our legislators are most effective in positively shaping our communities, our state, and our nation.

\section{References}

Online sunshine. (2018). http://www.leg.state.fl.us/
Effective communication with legislators. (2018). https:// www.flsenate.gov/About/EffectiveCommunication 